\title{
The Synthesis of 1,4,7-Triazacyclononane Conjugated Amyloid-phillic Compound and Its Binding Affinity to the $\boldsymbol{\beta}$-Amyloid Fibril
}

\author{
Jongmin Kang* and Jee Hye Jo \\ Department of Applied Chemistry. Seiong lniversity, Seoul /43-747. Korea \\ Received.hily 7,2003
}

Key Words : $\Lambda$ lzheimers disease, $\beta$-Amyloid fibril, $\Lambda$ myloid-philic molecule

The pathological hallmark of $A D$ is a deposition of anyloid plaques in the brains of patients. $\beta$-amyloid protein is a major protein component of Alrheimer's placues. When aggregated into anyloid fibrils, the peptide is toxic to neuronal cells. ${ }^{1.2}$ The neurotoxicity of $A \beta$ fibril is closely related to the $\beta$-sheet conformation and aggregation of $\mathrm{A} \beta$ peptide..$^{3}$ Various compounds which have affinity for $\beta$ amyloid fibril have shown ability of preventing neurotoxicity of $\beta$-amyloid fibril and inhibiting aggregation of $\beta$-amyloid fibri]." Therefore, the development of new compounds which have atfinity for the $\beta$-amyloid fibril would lead to the new compounds that could have therapeutic effects on AD. Previously, we generated new anyloid-phillic amide derivative of Chrysamine $\mathrm{G} \mathbf{I}$ and found that this compound protect human astrocyte cells against $\mathrm{A} \beta$-induced toxicity. ${ }^{5.6}$ As conjugation of anyloid-philic molecules with suitable metal chelating ligands could lead to new diagnostic molecules for in vivo quantification of anyloid deposition ${ }^{7.8}$ and new probes for amyloid structure. "10 we designed the compound 2, which was conjugate of 1,4,7-triazacyclononane and the amyloid-philic compound 1 . Here, we would like to report the synthesis of compound 2 and its binding property of $\beta$-amyloid tibril. The synthesis of compound 2 was achieved by combining three fragments the biphenyl amine 9, isophthalic acid $\mathbf{5}$ and 1,4,7-triazacyclononane $\mathbf{2 0}$.

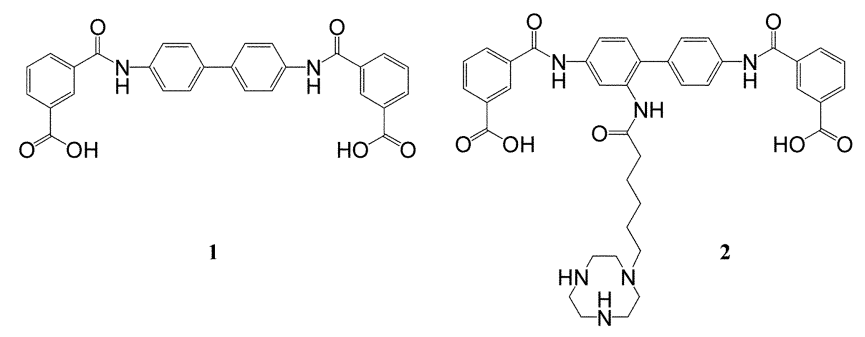

The synthesis of isophthalic acid part 5 commenced with esterfication of isophthalic acid in methanol with HCl to produce the monoester 4 in $38 \%$ yield. Treatment of the monoester 4 with oxalyl chloride afforded the acyl chloride 5 in $95 \%$ yield (Scheme 1).

The synthesis of biphenyl amine part 9 began with the reaction between 4,4-dinitro-2-biphenylamine 6 and 6bromohexanoyl chloride 7 in dried methylene chloride to afford compound 8 in $92 \%$ yield. Hydrogenation of the compound 8 at elevated pressure with $\mathrm{Pd} C \mathrm{C}$ gave the biphenyl amine 9 in $99 \%$ yield (Scheme 2).

The synthesis of 1,4-bis(tert-butylcarbonate)-1,4,7-triazacyclononane 20 started fiom tosylation of diethylenetriamine 12. Therefore, the reaction between diethylenetriamine and tosylchloride gave the tosylated diethylenetriamine 13 in 93 $\%$ yield. Then tosylated diethylenetriamine 13 was refluxed<smiles>O=C(O)c1cccc(C(=O)O)c1</smiles>

3

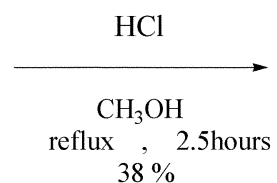

$-\mathrm{NO}_{2}$

6

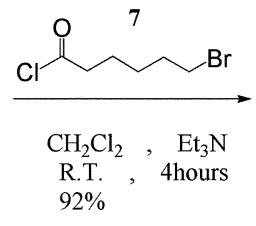<smiles>COC(=O)c1cccc(C(=O)O)c1</smiles>

4

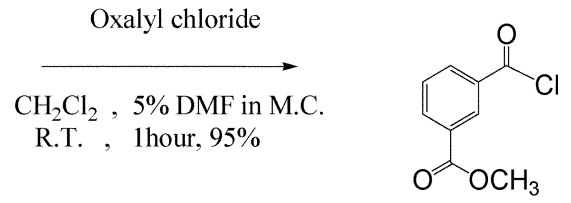

5

Scheme 1
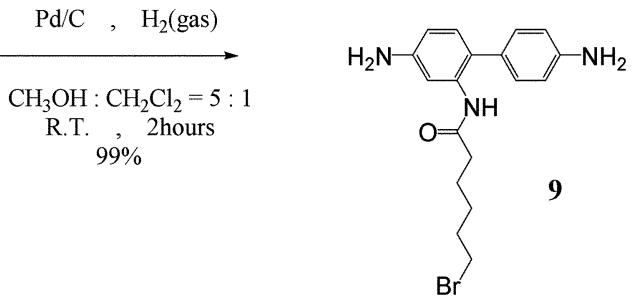

Scheme 2 

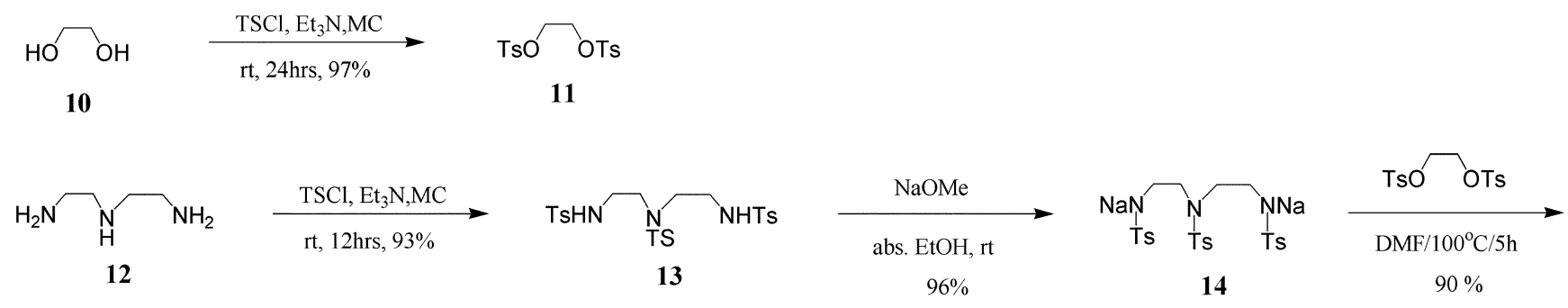

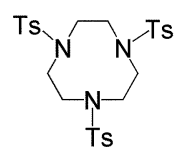

15<smiles>c1ccc(CN2CCNCCNC2)cc1</smiles>

18

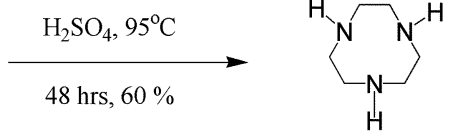

16

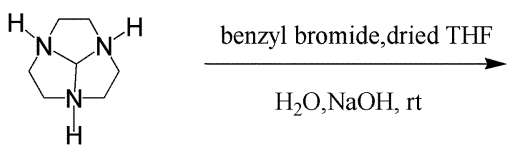

17

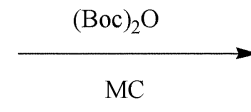

$\mathrm{MC}$

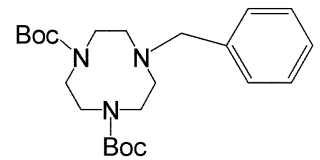

19

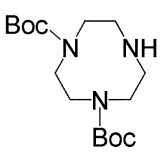

20

Scheme 3

in absolute ethanol with sodium methoxide to give sodium metallated compound $\mathbf{1 4}$ in $96 \%$ yield. Metallated compound 14 was reacted with tosylated ethylene glycol 11 in hot and dried DMF to give tritosylated-1,4,7-triazacyclononane 15 in $90 \%$ yield. Detosylation of the compound 15 was performed in hot sulfuric acid for 48 hours to give the 1.4,7-triazacyclononane 16 in $60 \%$ yield. The 1.4.7-triazacyclononane 16 was reacted with N.N'-dimethylformamide dimethylacetal to give the protected 1,4.7-triazacyclononane 17 in $85 \%$ yield. The protected 1.4.7-triazacyclononane 17 was reacted with benzyl bromide in dried $\mathrm{THF}$ to give the $\mathrm{I}$ benzyl-1,4,7-triazacyclononane $\mathbf{1 8}$ in quantitative yield. Then the compound 18 was reacted with dibutyldicarbonate in methylene chloride to give the compound 19 in quantitative yield. Debenzylation of the compound 19 with $10 \% \mathrm{Pd} / \mathrm{C}$ in acetic acid gave the desired 1,4-bis(tertbutylcarbonate)-1.4,7-triazacyclononane 20 in $81 \%$ yield (Scheme 3).

The coupling of three fragments was accomplished by the reaction of the biphenyl compound $\mathbf{9}$ and the acyl chloride 5 to afford the molecule $\mathbf{2 1}$ in $30 \%$ yield. Refluxing the compound $\mathbf{2 0}$ and $\mathbf{2 1}$ in acetonitrile gave the compound $\mathbf{2 2}$ in $71 \%$ yield. Deprotection reaction of 22 in $4 \mathrm{M} \mathrm{HCl}$ dioxane and neutralization of the deprotected compound with $6 \mathrm{~N} \mathrm{LiOH}$ gave the final compound 2 as a lithiated form (Scheme 4).

As lithiated salt form, the compound $\mathbf{2}$ was readily soluble in water. For the binding study, $80 \mu \mathrm{L}$ of various concen-

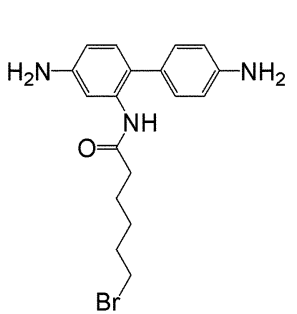

9

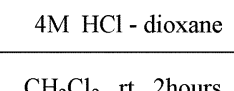

$\mathrm{CH}_{2} \mathrm{Cl}_{2}, \mathrm{rt}$, 2hours
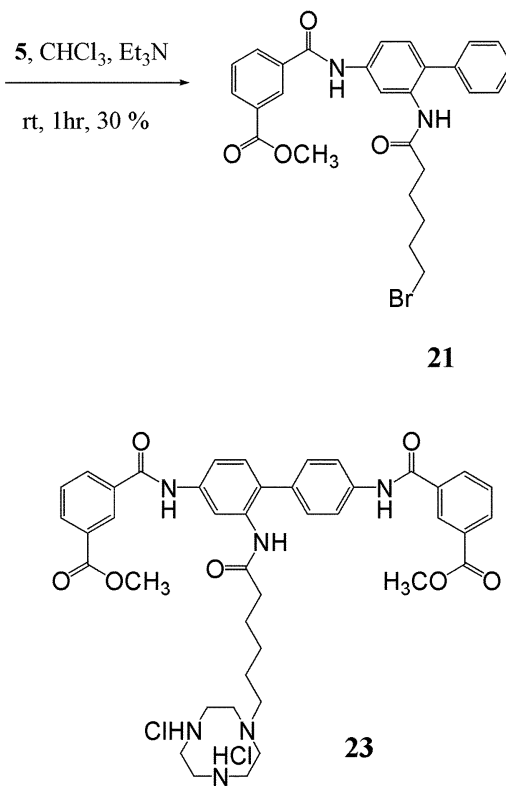
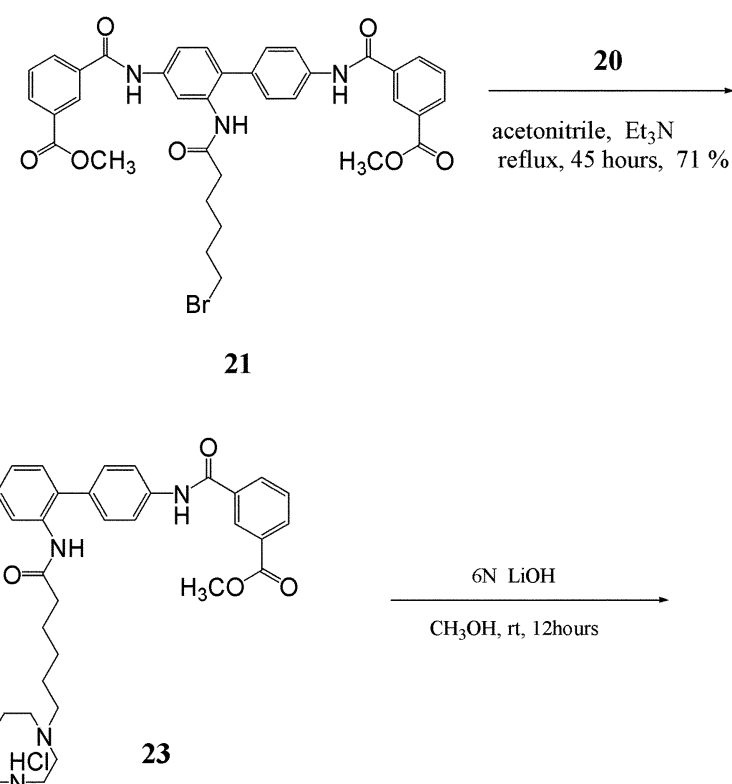

Scheme 4
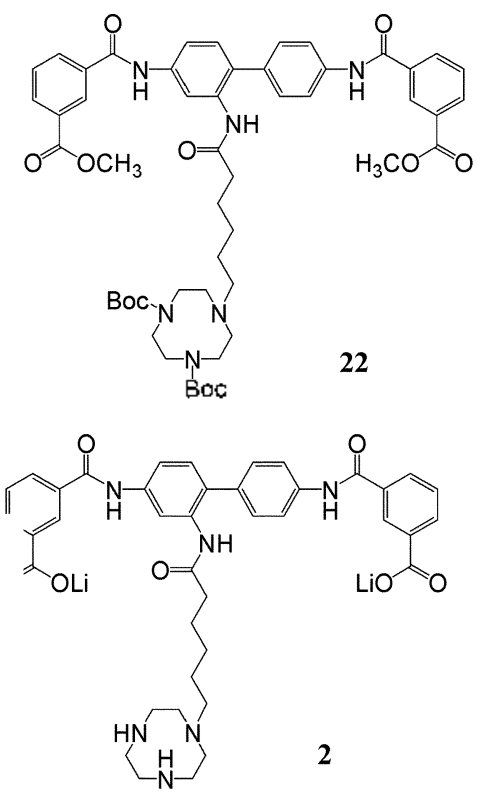


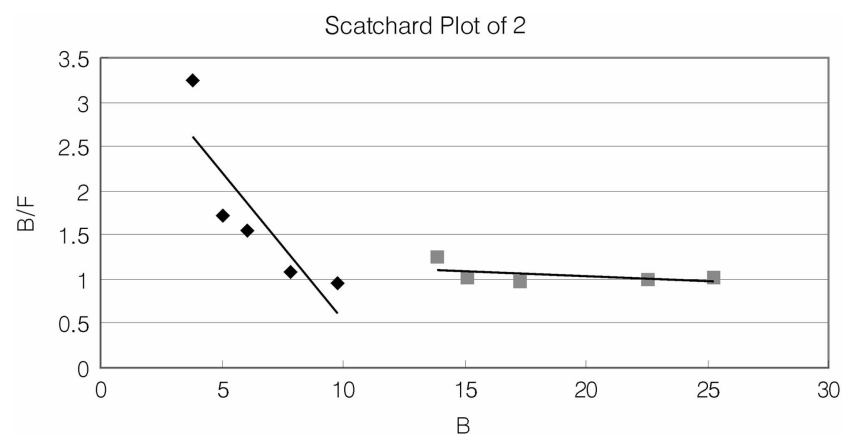

Figure 1. The Scatchard analysis of the compound 2 for the $\beta$ amyloid fibril 1-40.

trations of the compound 2 in water $(5-100 \mu \mathrm{M})$ were added to the $20 \mu \mathrm{L}$ of $100 \mu \mathrm{M} \beta$-anyloid 1-40 fibril. After 2 hours at $37^{\circ} \mathrm{C}$, the incubating eppendorf tubes were centrifuged ( $16.000 \mathrm{rpm}, 20 \mathrm{~min}$ ) to spin down the $\beta$-amyloid fibril and the compound bound to the $\beta$-amyloid fibril. Then the concentrations of unbound compound in the solution were measured by UV spectrometer at $290 \mathrm{~nm}$. Figure 1. shows Scatchard analysis of the binding of 2 to the $\beta$-amyloid $1-40$ fibril. Like compound 1, 2 has two binding sites. The higher affinity binding site appears to have a $\mathrm{K}_{\mathrm{d}}$ of $2.98 \mu \mathrm{M}$ and a $\mathrm{B}_{\text {mux }}$ of 0.58 moles per mole of anyloid $1-40$ peptide. The lower affinity binding site appears to have a $\mathrm{K}_{\mathrm{d}}$ of $88.50 \mu \mathrm{M}$ and $a B_{\text {ula }}$ of 5.60 moles per mole of $\beta$-amyloid $1-40$ peptide. As the compound 1 showed $\mathrm{K}_{\mathrm{d}}=0.13, \mathrm{~B}_{\mathrm{ml1s}}=0.36$ at higher affinity binding site and $\mathrm{K}_{\mathrm{d}}=10.1 \mathrm{I} \mathrm{B} \mathrm{B}_{\text {tnax }}=0.60$ at lower affinity binding site, the compound 2 has comparable affinity with the compound $\mathbf{l}$ or Chrysamine G. ${ }^{5.6}$ The coupling of 1,4,7-triazacyclononane to the compound $1 \mathrm{did}$ not affect the binding affinity of the molecule 2 . The molecule 2 could be used to as a new diagnostic molecule for quantification of amyloid deposition or new probes for amyloid structure after metal chelation. The possibilities are currently under investigation.

\section{Experimental Section}

Monomethyl isophthalate 4. To a solution of $2 \mathrm{~g}$ isophthalic acid in $60 \mathrm{~mL}$ of methyl alcohol was added 3 drops of concentrated $\mathrm{HCl}$ and refluxed for 2.5 houl's. After evaporation of methyl alcohol the reaction mixture was chromatographed on silicagel with $7 \% \mathrm{MeOH}-\mathrm{MC}$ to afford $839 \mathrm{mg}$ product 4 in $38 \%$ yield. ' $\mathrm{H}$ NMR $\left(200 \mathrm{MHz}_{\mathrm{C}} \mathrm{CDCl}_{3}\right)$ $8.8(\mathrm{t}, 1 \mathrm{H}, J-1.6) 8.3(\mathrm{dd}, 2 \mathrm{H}, J-8.0, j-1.6) 7.6(\mathrm{t}, \mathrm{IH}, J$ - 8.0) $4.0(\mathrm{~s}, 3 \mathrm{H}) \mathrm{MS}$ calculated for $\mathrm{C}_{8} \mathrm{H}_{8} \mathrm{O}_{4} \mathrm{I} 80 . \mathrm{I}$ found for $179.0(\mathrm{M}-\mathrm{H})$.

Monomethylester isophthaloyl chloride 5 . To a solution of $730 \mathrm{mg} 4 \mathrm{in} 15 \mathrm{~mL}$ of dichloromethane was added $3.5 \mathrm{~mL}$ of oxalyl chloride and $150 \mu \mathrm{L}$ of $5 \%$ DMF-MC. After stitring an hour, evaporation of all solvent and oxalyl chloride at reduced pressure produced the compound $\mathbf{5}$ in 95 $\%$ yield. ${ }^{1} \mathrm{H}$ NMR (200 MHz, CDCI $) 8.6$ (t. I H, $\left.J-\mathrm{I} .6\right) 8.2$ $(\mathrm{m}, 2 \mathrm{H}) 7.5(\mathrm{t}, \mathrm{IH}, J-7.8) 3.9(\mathrm{~s}, 3 \mathrm{H})$.

Compound 8. To a solution of 2 g 4.4-dinitro-2- biphenylaniline and $1.3 \mathrm{~mL}$ triethylamine in $80 \mathrm{~mL}$ of dried dichloromethane was added $1.4 \mathrm{~mL}$ 6-bromohexanoyl chloride and stirred for 4 hours. Then the reaction mixture was extracted with $100 \mathrm{~mL}$ of water three times. The organic layer was dried with $\mathrm{MgSO}_{4}$ and filtered. Evaporation of filtrate and silicagel chromatography (hexane: dichloromethane $=4: 1$ ) gave $550 \mathrm{mg}$ of product 8 in $92 \%$ yield. ' $\mathrm{H}$ NMR (200 MHz, CDCl 1 ) 9.1 (d. I H, $J=2.2) 8.4$ (d. 2H, $J=$ 6.8 ) 8.1 (dd, IH, $J=8.4, J=2.2) 7.6(\mathrm{~d}, 2 \mathrm{H}, J=6.8$ ) $7.4(\mathrm{~d}$, $1 \mathrm{H}, J=8.4) 7.0(\mathrm{~s}, 1 \mathrm{H}) 3.4(\mathrm{t}, 2 \mathrm{H}, J=6.5) 2.3(\mathrm{t}, 2 \mathrm{H}, J=7 . \mathrm{l})$ 1.8 (quin, $2 \mathrm{H}, j=7.0$ ) I.7 (quin, $2 \mathrm{H}, J=8.0$ ) 1.5 (quin, $2 \mathrm{H}$, $J=6.6) \mathrm{MS}$ calculated for $\mathrm{C}_{18} \mathrm{H}_{18} \mathrm{BrN}_{3} \mathrm{O}_{5} 435.0$ found for 434.8 .

Compound 9. A solution of $1 \mathrm{~g}$ compound 8 and $250 \mathrm{mg}$ $10 \% \mathrm{Pd} / \mathrm{C}$ in $20 \%$ methanol in dichloromethane was stirred with $\mathrm{H}_{2}$ gas at elevated pressure for 2 hours. The solution was filtered through celite and the filtrate was evaporated to afford $862 \mathrm{mg}$ product 9 in $99 \%$ yield. 'H NMR $(200 \mathrm{MHz}$, $\left.5 \% \mathrm{CD}_{3} \mathrm{OD}-\mathrm{CDCl}_{3}\right) 7.5(\mathrm{~d}, \mathrm{IH}, J=2.3) 7.0(\mathrm{~d}, 2 \mathrm{H}, J=8.3)$ $6.9(\mathrm{~d}, \mathrm{IH}, J=8.2) 6.7(\mathrm{~d}, 2 \mathrm{H}, J=8.3) 6.5(\mathrm{dd}, 1 \mathrm{H}, J=8.2, J$ $=2.3) 3.3(\mathrm{t}, 2 \mathrm{H}, J=5.7) 2 . \mathrm{l}(\mathrm{t}, 2 \mathrm{H}, J=7.0) 1.7$ (quin, $2 \mathrm{H}, J$ $=6.6$ ) 1.5 (quin, $2 \mathrm{H}, J=7.3$ ) 1.3 (quin, $2 \mathrm{H}, J=6.4$ ) MS calculated for $\mathrm{C}_{18} \mathrm{H}_{22} \mathrm{BrN}_{3} \mathrm{O} 375 . \mathrm{l}$ found for 296.1 (M-HBr).

Ditosyl ethylene glycol 11. To a solution of $29 \mathrm{~g}$ triethylamine and $55 \mathrm{~g}$ tosyl chloride in $200 \mathrm{~mL}$ of dichloromethane at 0 ' $\mathrm{C}$ was added $8 \mathrm{~g}$ ethylene glycol for an hour. Then the reaction mixture was stirred for 24 hours. The reaction mixture was poured into $2 \mathrm{~L}$ water and extracted with $100 \mathrm{~mL}$ of dichloromethane 5 times. The organic layer was dried with $\mathrm{MgSO}_{1}$ and filtered. Evaporation of dichloromethane produced $47 \mathrm{~g}$ of compound 11 in $97 \%$ yield. ' $\mathrm{H}$ $\operatorname{NMR}\left(200 \mathrm{MHz}, \mathrm{CDCl}_{3}\right) 7.7(\mathrm{~d}, 4 \mathrm{H}, J=8.2) 7.3(\mathrm{~d}, 4 \mathrm{H}, J=$ 8.2) $4.2(\mathrm{~s}, 4 \mathrm{H}) 2.5(\mathrm{~s}, 6 \mathrm{H})$.

Tritosyl diethylenetriamine 13. To a solution of $25.2 \mathrm{~g}$ triethylamine and $8 \mathrm{~g}$ diethylenetriamine in $350 \mathrm{~mL}$ dichloromethane was added $45.8 \mathrm{~g}$ tosylchloride at $0{ }^{\circ} \mathrm{C}$. Then the reaction mixture was stirred for 12 hours. Evaporation of the solvent and recrystallization in methanol gave $41.4 \mathrm{~g}$ of product 13 in $93 \%$ yield. 'H NMR (200 MHz, $\left.\mathrm{CDCl}_{3}\right) 7.6(\mathrm{~d}, 4 \mathrm{H}, J-8.2) 7.3(\mathrm{~d}, 4 \mathrm{H}, J-8.2) 5 . \mathrm{l}(\mathrm{t}, 2 \mathrm{H})$ 3.1 (t. $8 \mathrm{H} . J-6.8) 2.4$ (s. $9 \mathrm{H})$.

Compound 14. To a solution of $32 \mathrm{~g}$ of the compound 13 in $310 \mathrm{~mL}$ ethanol was added $23 \mathrm{~g}$ of $28 \% \mathrm{MaOMe}$ and refluxed for 2 hours. Filtration of the solid afforded the compound 14 in $96 \%$ yield. 'H NMR (200 MHz, CDC. $7.46(\mathrm{~d}, 6 \mathrm{H}, J-8.0) 7.28(\mathrm{~d}, 2 \mathrm{H}, J-8.0) 7 . \mathrm{I}(\mathrm{d}, 4 \mathrm{H}, J-$ $8.0) 2.83(\mathrm{~m}, 4 \mathrm{H}) 2.62(\mathrm{~m}, 4 \mathrm{H}) 2.83(\mathrm{~m}, 4 \mathrm{H}) 2.62(\mathrm{~m}, 4 \mathrm{H})$ $2.34(\mathrm{~s}, 3 \mathrm{H})$.

Tritosyl 1,4,7-triazacyclononane 15 . To a solution of 28 $\mathrm{g}$ of the compound 14 in $180 \mathrm{~mL}$ dried DMF at $100^{\circ} \mathrm{C}$ was added $17 \mathrm{~g}$ of the compound 11 in $150 \mathrm{~mL}$ dried DMF for 2 hours. Then the reaction mixture was stirred for 2 hours more at $100^{\circ} \mathrm{C}$. Evaporation of the DMF at reduced pressure and recrystallization in water gave the $24.5 \mathrm{~g}$ of the compound 15 in $90 \%$ yield. 'H NMR (200 MHz, CDCl $)$ $7.65(\mathrm{~d}, 6 \mathrm{H}, J-8.0) 7.28(\mathrm{~d}, 6 \mathrm{H}, J-8.0) 3.40(\mathrm{~s}, \mathrm{I} 2 \mathrm{H}) 2.4 \mathrm{I}$ (s. 9H). 
1,4,7-Triazacyclononane 16 . The solution of $25.6 \mathrm{~g}$ of the compound 15 in $55 \mathrm{~mL}$ concentrated $\mathrm{H}_{2} \mathrm{SO}_{4}$ was heated at $95^{\circ} \mathrm{C}$ for 48 hours. Then the reaction mixture was slowly poured into $300 \mathrm{~mL}$ of cold diethyl ether and ethanol $(\mathrm{l}: \mathrm{l})$ The solid was filtered and dissolved in water and $\mathrm{pH}$ was adjusted until 8 with $6 \mathrm{~N} \mathrm{KOH}$. Then all of the water was evaporated and the residue was dissolved in small amount of methanol. The undissolved $\mathrm{KOH}$ was removed by filtration. This method gave the product 16 in $60 \%$ yield. ${ }^{1} \mathrm{H}$ NMR $\left(200 \mathrm{MHz} . \mathrm{CDCl}_{3}\right) 2.7$ (s. 12H) 1.9 (s. $1 \mathrm{H}$ ).

Compound 17. To a solution of $0.2 \mathrm{~g}$ conpound 16 in 18 $\mathrm{mL}$ dried acetonitrile was added $11 \mathrm{~mL} \mathrm{~N}, \mathrm{~N}^{\prime}$-dimethylformamide dimethyl actal. The reaction mixture was stirred for 3 hours at $85{ }^{\circ} \mathrm{C}$. Evaporation of the solid gave $0.17 \mathrm{~g}$ of the product 17 in $85 \%$ yield. ${ }^{~} \mathrm{H}$ NMR ( $200 \mathrm{MHz}$. $\left.\mathrm{CDCl}_{3}\right) 5.0$ (s. 1H) $2.6-3.0(\mathrm{~m}, 12 \mathrm{H})$.

1-Benzyl-1,4,7-triazacyclononane 18 . To a solution of $6.6 \mathrm{~g}$ of the compound 17 in $65 \mathrm{~mL}$ dried THF was added $6.7 \mathrm{~mL}$ benzyl bromide. Then the reaction mixture was stirred for an overnight. After the solvent was evaporated. 55 $\mathrm{mL}$ of water and $2 \mathrm{~g} \mathrm{NaOH}$ was added to the reaction mixture and refluxed for 2 days. The reaction misture was extracted with chloroform and the organic layer was dried with $\mathrm{MgSO}_{4}$. Filtration and evaporation of the filtrate gave the product 18 in quantitative vield. The product obtained in this stage was crude. Without further purification this material was used for the next reaction.

1,4-Bis(tert-butylcarbonate)-7-benzyl-1,4,7-triazacyclononane 19. To a solution of $8.9 \mathrm{~g}$ of the conpound 18 in 250 $\mathrm{mL}$ dichloromethane was added $35 \mathrm{~g}$ dibutyldicarbonate. Evaporation of the solvent and chromatography (hexane ethyl acetate $=8: 1$ ) on silicagel gave product 19 in quantitative yield. ${ }^{\prime} \mathrm{H}-\mathrm{NMR}\left(200 \mathrm{MHz}, \mathrm{CDCl}_{3}\right) 7.2(\mathrm{~m} .5 \mathrm{H})$ 3.63 (s. $2 \mathrm{H}) 3.43$ (t. $4 \mathrm{H}) 3.14(\mathrm{~m} .4 \mathrm{H}) 2.61(\mathrm{~m}, 4 \mathrm{H}) 1.38$ (s. $9 \mathrm{H})$.

1,4-Bis(tert-butylcarbonate)-1,4,7-triazacyclononane 20. To a solution of $\mathrm{lg}$ of the conpound 19 in $25 \mathrm{~mL}$ acetic acid was added $0.1 \mathrm{~g} 10 \% \mathrm{Pd} / \mathrm{C}$ and stirred under $\mathrm{H}_{2}$ gas atmosphere for 3 hours. The reaction mixture was filtered through celite and the filtrate was evaporated. The residue was dissolved in small amount of water and $\mathrm{pH}$ was adjusted until 12 with $1 \mathrm{~N} \mathrm{NaOH}$. The water lay'er was extracted with $50 \mathrm{~mL}$ chloroform 3 times. The organic layer was dried with $\mathrm{MgSO}_{4}$. Filtration and evaporation of the filtrate gave $0.6 \mathrm{~g}$ of the compound 20 in $81 \%$ yield. 'H-NMR (200 MHz. $\mathrm{CDCl}_{3}$ ) 3.47 (t. $\left.4 \mathrm{H}\right) 3.32$ (b. $\left.4 \mathrm{H}\right) 2.97$ (m. $4 \mathrm{H}$ ) 1.47 (s. 9H).

Compound 21. To a solution of $1.0 \mathrm{~g}$ of the compound 9 and $1.1 \mathrm{~mL}$ triethylamine in $10 \mathrm{~mL}$ chloroform was added compound 5 . The reaction mixture was stirred for an hour. Evaporation of the solvent and chromatography on the silicagel (methanol : dichloromethane $=7: 493$ ) gave 578 mg of the product 21 in $30 \%$ yield. ${ }^{1} \mathrm{H}$ NMR $\left(10 \% \mathrm{CD}_{3} \mathrm{OD}-\right.$ $\left.\mathrm{CDCl}_{3}\right) 8.5$ (s. $\left.2 \mathrm{H}\right) 8.0(\operatorname{td} .4 \mathrm{H} . J=7.8 \mathrm{~J}=1.3) 7.9(\mathrm{~d} .1 \mathrm{H} . J$ $=2.0) 7.8($ dd $.1 \mathrm{H} . J=8.4 . J=2.0) 7.7$ (d. $2 \mathrm{H} . J=8.5) 7.5$ (td. $2 \mathrm{H} . J=7.8 . J=1.3$ ) 7.3 (d. $2 \mathrm{H} . J=8.5$ ) 7.2 (d. $1 \mathrm{H} . J=$ $8.4) 3.8$ (s. $6 \mathrm{H}$ ) 3.3 (t. $2 \mathrm{H} . J=6.7$ ) 2.2 (t. $2 \mathrm{H} . J=7.1$ ) 1.8 (quin. $2 \mathrm{H} . J=7.3$ ) 1.5 (quin. $2 \mathrm{H} . J=7.3$ ) 1.3 (quin. $2 \mathrm{H} . J=$
5.9) MS calculated for $\mathrm{C}_{36} \mathrm{H}_{34} \mathrm{BrN}_{3} \mathrm{O}_{7} 699.1$ found for 619.9 (M-Br).

Compound 22. To a solution of $550 \mathrm{mg}$ of the compound 21 and $0.3 \mathrm{~mL}$ trietlyylamine in $20 \mathrm{~mL}$ of actonitrile was added $259 \mathrm{mg}$ of the compound $\mathbf{2 0}$. The reaction mixture was refluxed for 45 hours. Evaporation of the solvent and chromatography on the silicagel ( $4 \%$ methanol in dichloromethane) afforded $113 \mathrm{mg}$ of the compound 22 in $71 \%$ yield. ${ }^{1} \mathrm{H}$ NMR $\left(\mathrm{CDCl}_{3}\right) 8.5$ (d. $\left.2 \mathrm{H}, J=1.6\right) 8.2$ (s. $\left.\mathrm{lH}\right) 8.1$ (m. $4 \mathrm{H}$ ) 7.9 (d, $2 \mathrm{H} . J=8.2) 7.5$ (td, $2 \mathrm{H} . J=7.9 . J=1.6) 7.4$ (d. $1 \mathrm{H} . J=7.8$ ) 7.3 (d. $2 \mathrm{H} . J=8.2) 7.2$ (d. $1 \mathrm{H} . J=8.4) 3.9$ (s, $6 \mathrm{H}) 3.4(\mathrm{~s}$, br. $4 \mathrm{H}) 3.1(\mathrm{~s}, 4 \mathrm{H}) 2.5(\mathrm{~s}$, br. $4 \mathrm{H}) 2.4(\mathrm{~m}, 2 \mathrm{H}) 2.2$ (m. $2 \mathrm{H}) 1.5(\mathrm{~m} .6 \mathrm{H}) 1.4(\mathrm{~m}, 18 \mathrm{H})$ MS calculated for $\mathrm{C}_{52} \mathrm{H}_{64} \mathrm{~N}_{6} \mathrm{O}_{11} 949.1$ found for $950.1\left(\mathrm{M}+\mathrm{H}^{+}\right)$.

Compound $23.30 \mathrm{mg}$ of the compound 22 was dissolved in $4 \mathrm{M} \mathrm{HCl}$ in dioxane $(0.4 \mathrm{~mL})$ and stirred for an hour. Evaporation of the solvent gave $26 \mathrm{mg}$ of the product $23 \mathrm{in}$ $99 \%$ yield. ${ }^{~} \mathrm{H}$ NMR $\left(\mathrm{CD}_{3} \mathrm{OD}\right) 8.6(\mathrm{t}, 2 \mathrm{H} . J=1.5) 8.2$ (t. $4 \mathrm{H}$, $J=7.7) 8.0(\mathrm{~d}, 1 \mathrm{H} . J=2.0) 7.8(\mathrm{~d}, 2 \mathrm{H}, J=8.6) 7.7(\mathrm{td}, 2 \mathrm{H} . J$ $=7.7, J=1.5) 7.6(\mathrm{~d}, 1 \mathrm{H}, J=2.1) 7.5(\mathrm{~d} .2 \mathrm{H} . J=8.6) 7.4(\mathrm{~d}$, IH. $J=4.4) 4.0(\mathrm{~d}, 6 \mathrm{H}, J=0.8) 3.6(\mathrm{~s} .4 \mathrm{H}) 3.3(4 \mathrm{H}) 3.0(\mathrm{~m}$. 4H) 2.8 (t. $2 \mathrm{H} . J=7.9$ ) 2.4 (t. $2 \mathrm{H} . J=6.9) 1.7(\mathrm{~m}, 4 \mathrm{H}) 1.3$ (m. 2H).

Compound 2. To a solution of $20 \mathrm{mg}$ of the compound 23 was added $60 \mathrm{~mL}$ of $6 \mathrm{~N} \mathrm{LiOH}$ and stirred for an overnight. Filtration of the precipitated solid afforded $17 \mathrm{mg}$ of litliated product 2 in $96 \%$ yield. ${ }^{1} \mathrm{H}$ NMR $\left(\mathrm{CD}_{3} \mathrm{OD}\right) 8.5(\mathrm{~m}, 2 \mathrm{H}) 8.2$ (d. 2 H. $J=7.6$ ) $8 . \mathrm{I}$ (d. $2 \mathrm{H} . J=7.6) 8.0$ (s. $1 \mathrm{H}$ ) 7.8 (d. $2 \mathrm{H} . J=$ $8.5) 7.7$ (d. $1 \mathrm{H}, J=8.8$ ) 7.5 (t. $2 \mathrm{H} . J=7.7$ ) 7.45 (d. $2 \mathrm{H}, J=$ 6.6) 7.4 (d. IH. $J=6.4) 2.6(\mathrm{~m} . \mathrm{l} 2 \mathrm{H}) 2.3(\mathrm{t}, 2 \mathrm{H}, J=7.3) 1.5$ (m. $4 \mathrm{H}) \mathrm{I} .3(\mathrm{~m} .2 \mathrm{H}) \mathrm{MS}$ calculated for $\mathrm{C}_{40} \mathrm{H}_{4: 2} \mathrm{Li}_{2} \mathrm{~N}_{6} \mathrm{O}_{7} 732.3$ found for $733.3\left(\mathrm{M}+\mathrm{H}^{+}\right)$.

Acknowledgement. This study was supported by a grant of the Korea Health 21 R\&D Project. Ministry of Health \& Welfare, Republic of Korea. (01-PJI-PG3-21500-0017)

\section{References}

1. Harrigan, M. R; Kunkel. D. D.; Nguven. L. B.; Malouf, A. T. Yeurobiol Aging 1995. 16.779.

2. Pike. C. T.: Walencewicz-wassermant. A. T.: Komoski. J.: Cribbs. D. H.: Glabe. C. G.: Cotman. C. W. J. Nemochent 1995. 64. 253.

3. Simmons. L. D.: Mav, P. C.: Tomaselli, K. T.: Rydel, R. E.: Fuson. K. S.: Brigham, E. F; Wright, S.: Lieberburg. I.; Becher, G. W: Brems. D. N.: Li, W. Y. Mol. Pharmacol 1994, 45. 373.

4. Schent. D. B.: Rydel. R. E.: May. P:Little. S.: Pantetta. T.: Lieberburg. I.: Sinha. S. J. Med Chem. 1995. 38(21). 4141 .

5. Kang. J.: Han. K. Bull. Korean Chent. Soc. 2001. $22(10)$. 1065.

6. Kang, J.: Park, J. E.; Jo, S. Bull. Korean Chem. Soc. 2002, 23(3). 363.

7. Han. H. Cho, C.G.: Lansbury. P. T.. Jr. J. Am. Chem Soc. 1996. 118. 4506 .

8. Dezulter. N. A.: Dom. R. T.: De Groot. T. J:: Bormans. G. M.: Verbruggen. A. M. Eur. J. Nucl. Hed 1999. HI. 1392.

9. Klunk. W. E.; Debnath. M. L.; Pettergrew: J. W. Nemobiology of Aging 1994. 15(6).691

10. Ashbum, T. T: Han. H: McGuinness, B. F.: Lansbury, P. T., Jr. Chemistry \& Biologv 1996. 3. 351 . 